Article

\title{
Building Sustainable Development through Technology Transfer in a Romanian University
}

\author{
Calin S. Vac ${ }^{1, *}$ and Avram Fitiu ${ }^{2, *}$ \\ 1 Department of Economic Sciences, University of Agricultural Sciences and Veterinary Medicine \\ Cluj-Napoca, 3-5 Manastur Street, 400372 Cluj-Napoca, Romania \\ 2 Department for Environmental and Plant Protection, University of Agricultural Sciences and Veterinary \\ Medicine Cluj-Napoca, 3-5 Manastur Street, 400372 Cluj-Napoca, Romania \\ * Correspondence: calin.vac@usamvcluj.ro (C.S.V.); afitiu@yahoo.com (A.F.); Tel.: +40-757-727-111 (A.F.)
}

Received: 31 August 2017; Accepted: 3 November 2017; Published: 9 November 2017

\begin{abstract}
To improve university and commercial ties with industry, many universities operate a technology transfer office (TTO) as a vehicle to support the creation of spin-off companies. Run effectively, the TTO can define roles and responsibilities, structures and processes that support the creation and development of new ventures. The challenge for universities is to create TTOs with the right skill set. This paper aims to analyze the TTO activities to support transforming research outputs into commercialization in the context of the University of Agricultural Sciences and Veterinary Medicine from Cluj-Napoca, Romania (UASVMCN). Throughout this paper, different commercialization channels, the roles of technology transfer offices and multiple associative structures are further discussed with a special focus on agricultural open innovations and technologies. This study contributes to sustainable development of both Academia and agricultural Industry research, development and commercialization activities by illustrating current innovation and technology transfer activities produced by UASVMCN and its own TTO as a catalyst entity, a new model in Romania, so that the Academia-TTO-Economy partners association draw a functional and productive triple helix. In order to assess the sustainability of using the above-mentioned TTO, the methodological tools involving analysis are implemented. Finally, this paper states that correct operating of a university TTO is a real opportunity for technology transfer, both from the perspective of an alternative to research funding or entrepreneurship, and from the cultural perspective of the university correlation to the current trends in research, innovation and technology transfer, on a unique and entrepreneurial European market.
\end{abstract}

Keywords: entrepreneurship; sustainable development; technology transfer office; innovation; bioeconomy

\section{Introduction}

Literature has quite a large array of definitions that describe the term technology transfer, which can be traced as far as 1980, with the signing of the Bayh-Dole Act or the Patent and Trademark Law Amendments Act, published on 12 December. This act reversed 35 years of public policy and gave universities and small businesses the unfettered right to own inventions that resulted from federally funded research [1]. Before this act, businesses and universities were not allowed to take ownership of inventions funded by the government.

Widely, the term refers to a range of strategies that promote the transfer of new innovations, knowledge, technologies, practices, and/or skills from one setting to another.

The most generally speaking, "technology transfer" term can be defined as the process of movement of technology from one entity to another. It can be estimated that the transfer was successful if the receiving entity can effectively use the technology transferred and eventually assimilate it [2]. 
More specifically, the term "technology transfer" is used to describe the process by which ideas and concepts are moved from the laboratory to the marketplace [3,4]. Some authors have attempted a broader definition where they find that technology transfer is the movement of knowledge, skill, organization, values and capital from the point of generation to the site of adaptation and application [5].

One of the definitions that the authors consider as the most suitable for the concept of technology transfer is formulated by Association of University Technology Managers [6,7]: "technology transfer is the process of designating the formal transfer to industry of discoveries resulting from university or private research, for marketing purposes under the form of new products and/or services".

Technology transfer offices (TTOs) are essentially institutions that bridges Academia with the Industry. To improve university and commercial ties with industry, many universities operate a TTO as a vehicle to support the creation of spin-off companies [8]. Run effectively, the TTO can define roles and responsibilities, structures and processes that support the creation and development of new ventures. The challenge for universities is to create a TTO with the right skill set [9].

The success of a TTO usually depends on a series of factors, of which the most important one is the involvement of academic researchers $[10,11]$.

For this reason, it is important to emphasize that technology transfer is a process, a series of milestones to be checked in order to transfer research into commercially viable products, regardless of the industry. In this process, the researcher has a key role, working with the TTO in a structured manner, within an ecosystem that bridges research, innovation and business efforts. A TTO thus offers such a liaison that helps companies and industrial partners to better cooperate with universities in order to access new knowledge and expertise to drive innovation through research collaboration, contracted services and consultancy, to identify and license new technologies and intellectual property (IP) relevant to their business.

Center for Disease Control (CDC) [12], for example, identifies seven steps that ascend to the transfer goals of a TTO, as shown in Figure 1: Invention, Invention Disclosure, Assessment, Protection, Marketing, Licensing and Financial Return.

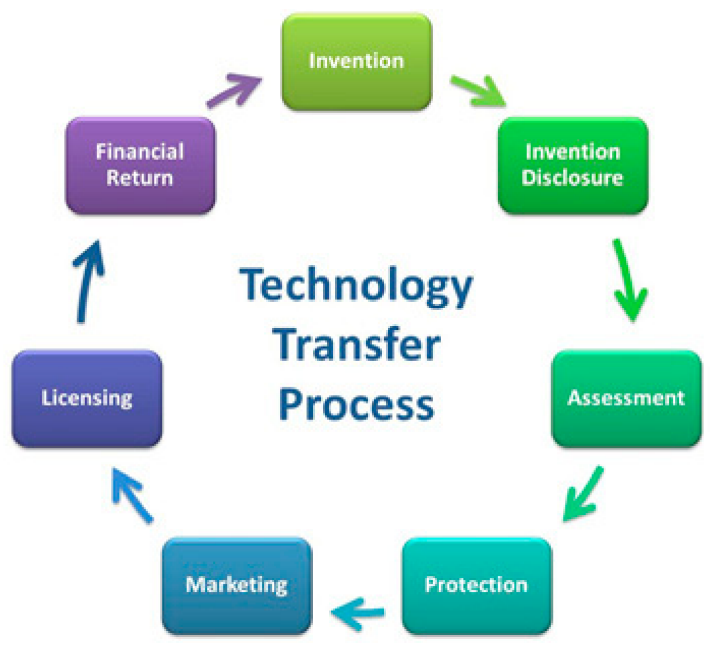

Figure 1. The process of technology transfer. Source: [12].

1. In the invention stage, the product or service is yet in a raw form, far from becoming a commercial product. The TTO can actively engage in this stage, providing guidance to the potential applicability of the emerging technology.

2. The invention disclosure stage, the inventor closely cooperates with the TTO at an instrumental level. Here, the TTO can help with developing the invention report, which serves as an initial documentation of the invention, in order to protect the patentability of the invention. 
3. During the assessment stage, the TTO discusses with the scientist in order to determine the marketability and patentability of the technology (evaluating its market potential). The activities most commonly used in this stage by the TTO specialist is the analysis of the technology and the technical details, searching patent databases and drafting a report completing the one elaborated by the researcher.

4. Protection refers to the patent application process. This is a usually long process, lasting around three years, during which the primary role is assigned to the TTO. If the product is indeed marketable, its protection allows inventors and commercial partners to recover financial investments made to commercialize the product.

5. Marketing. In this phase, the TTO drafts short non-confidential summaries for the technology that is available for licensing. Essentially, the TTO works with the inventor in order to identify potential commercial partners and potentially unmet markets.

6. As far as licensing is concerned, the TTO helps the inventor with the whole process, negotiates the licensing, responsibility, rights and terms and conditions. During this stage, the TTO negotiates the contract with the commercial partners.

7. Financial return. Efforts are made to ensure the post-license compliance. It is imperative that the TTO keeps track of the agreed upon technological developments, payment of royalties and compliance with the provisions of the agreement.

The choice and arrangement for the technology transfer is an immediate result of a few elements, for example, corporate vision, business necessities and the general organization game plan. Thus, technology can only be transferred if a series of actors have set out a common framework through complementary objectives. In this respect, Blohmke [13] states that local technology needs and socio-technical circumstances are important towards economic development induced by technology transfer. However, this methodology is not enough for the accomplishment of technology transfer, in order to ultimately deliver financial advancement.

The 7-phase CDC model of technology transfer can be broadly applied to the valorization of public research. However, Abrams [14] states that private TTOs are more likely to be more profitable than public ones. Moreover, research institutes' TTOs are more profitable than the ones of universities or hospitals.

Researchers find that US TTOs place a greater emphasis on "generating revenue" as an objective and they employ more staff who have experience in the industry sector and who might be more skilled at negotiating the financial clauses of licensing contracts than European TTOs.

The Chair of Economics and Management of Innovation has issued a report [15] that encompassed the results of a survey addressed to the TTOs of 211 universities located in Western European countries whose researchers published more than 200 scientific articles in the period 2004-2006. The report showed some traits of the European TTOs, such as the fact that they are fairly young: $60 \%$ of the analyzed TTOs were created in the last ten years. Moreover, the average TTO in the sample had 2.9 employees with a Ph.D. degree in Science and Engineering, 2.5 employees with five years of experience or more in industry and a total of 10.8 employees. The report also states that $29 \%$ of the investigated TTOs receive a share of licensing income or industry-sponsored contracts. In terms of start-ups, licenses and industry-supported researches, the report gives an extensive breakdown of the main activities of the TTOs, grouped geographically. For instance, TTOs from Ireland, the UK, Belgium, Switzerland and Denmark make more licenses than the European average. Also, TTOs from Sweden, The Netherlands, Finland, Switzerland and Germany make more start-up than the European average. Furthermore, TTOs from Denmark, Spain, Switzerland and France make more industry sponsored research contracts than the European average. However, Europe is seen to linger behind the US in bridging Academia with the Industry, namely in converting research to innovation.

However, Conti and Gaule [16] found that European TTOs don't execute fewer licenses than US TTOs. Notwithstanding, they win fundamentally less income from licenses. The distinction in licensing incomes is due to the contrasts in the association and staffing of TTOs. In particular, US TTOs use 
more staff with involvement in industry and seem to have more prominent adaptability in managing their budgets.

The literature places TTO (as Transfer Centers) as vital avenues for knowledge termed as scientific institutes [17], public and private research institutes [18,19], regional public research organizations [20], research institutes [21], Transfer Centers [22] or research centers [23].

For instance, at the request of the economic world (Walloon Union of Companies, Agoria and Liege Chamber of Commerce), the University of Liege (Belgium) had the initiative to create, in 1989, the first TTO (as a Company-University Interface) that aims at reviving the liaison between the University and its external, mainly industrial, partners. The TTO also has a task of advice and support for the university teams in the economic valuation of their research activities and to ensure the involvement of the university in the local and regional economic development and technological leadership [24].

In addition, at the Wageningen University, The Netherlands, the agricultural technology transfer activities are supported by The Centre for Development Innovation, a TTO office inside the university, linking research institutions, extension systems and producers to a market driven approach to variety development and dissemination [25]. They work on processes of innovation and change through facilitating innovation, brokering knowledge and supporting capacity development.

One of the most important networks of technology transfer centers in Central and Eastern Europe was created by Steinbeis Europa Zentrum Foundation from Germany in 2013, a technology transfer catalyst institution, creating TTOs inside more agricultural universities in Romania, Slovakia, Hungary, Serbia, Croatia, Bulgaria, Ukraine, Moldavia, Austria and Germany under the project "Danube Transfer Centers (DTC)" and implementing Steinbeis technology transfer model (technology transfer catalyst center), a model tested and validated in several universities and research institutions in Germany [6]. From this perspective, an example closer to the Romanian specific, more advanced and experienced and good to follow for our university to improve relations and intensify exchanges with the Economic environment, is the University of Natural Resources and Life Sciences, Vienna, Austria. This university includes a TTO specialized in Project Management Services (pre-award counseling to national, European and international funding programs and general administrative/technical information on and about project submission) and technology transfer services (support on service inventions, patenting and licensing, spin-offs and assists Boku researchers in commercializing innovative ideas), which is very active on both directions [26].

Whether we take European or US TTOs into account, one conclusion is common to both areas: if the academic institutions are to bring marketable benefits to their research, they must invest in their technology transfer operations.

In order for the TTO to work as seamless as possible, it needs to become a legitimate entity of the university or research body. Several authors $[27,28]$ state that TTOs need to be legitimately distinct, but kept in mind that they must not differentiate themselves too much from the university as a whole and risk to become irrelevant. However, managing intellectual capital is a bothersome task sometimes, as the TTO needs to be resilient enough to grant the needs and issues of the inventors. Bozeman [29] states that due to the fact that public funding is consistently constrained, an efficient TTO needs to help generate earnings such as licensing incomes and needs to protect existing research activities.

From all of the above approaches, it is clearly to see that any process of technology transfer must involve at least two protagonists, whatever they name them: Academia vs. Economy, or RDI (Research, Development \& Innovation) vs. the consumer market, or models creators (inventors) vs. results beneficiaries (customers, consumers). We have said "at least two protagonists" because, in a modern approach, alongside them, there is a third entity, namely the catalyst institutes (governance), which ensure the good functioning of the Academic-Economic relationship, thus forming what is today called triple helix [30]. Consequently, technology transfer may be initiated by one of the three entities. On the other hand, we believe that initiating the process is not the key to success, but the sustainability of this process because it is a great resource consumer. 
From this perspective, referring to the agricultural area in Romania, the technology transfer could be theoretically initiated and sustained from three directions.

First, Economy: as we stated recently [6], Romanian market economy is still recently (after 1989), with a poor experience, with an underdeveloped and almost unpredictable legal framework, having insufficient entrepreneurial education and culture of the RDI sector, but especially a poor capacity to fund RDI and technology transfer activities. A recent survey (October 2015) indicates that, at the national level, only 2.7\% from the total active SMEs (Small and Medium Enterprises) acts in agriculture area, the majority being micro-enterprises [31]. Agricultural workers in Romania (December 2016) have an average age of 35-49 years and a high school education [32], and the last report of the Romanian Center for European Policies reveals that in 2010 only 2.5\% of managers of agricultural farms were graduates of agricultural education (basic or full-time education) (compared to $7.3 \%$ in 2005), well below the European average of $29.6 \%$ [33]. However, another recent study (2014) conducted among farmers in Romania and published by the National Rural Development Network shows that they are fully aware that innovation and the associated transfer of knowledge are vital development tools for rural Europe. Innovation is a factor of Social, Economic and Environmental progress. Knowledge transfer supports the innovation process by keeping informed businesses, organizations and individuals and by fostering the exchange of ideas on new practices that can have a decisive influence. Romanian farmers understand that innovation is about creating the link between science and practice, and that it can rely on completely new ideas and cutting-edge research. Pilot projects, the development of new production methods and the provision of services are practical ways to improve the socio-economic development of rural areas. A new idea can be a new product, a new practice, a new service, a new production process, a new way of organizing things, etc. Such a new idea turns into innovation only if it is adopted on a large scale and proves its usefulness in practice. This will not only depend on the idea itself, but also on the market (farmers) possibilities to adopt this idea. Consequently, even if they do not have the capacity to successfully support innovation and technology transfer, SME farmers still want to be part of the triple helix [34].

Second, catalyst institutions: we also stated recently [6] that in Romania there is a complete lack of catalyst research and development management structures. However, in recent years, a series of specialized clusters and other governance structures have emerged in Romania, which give the prospect of further development of this sector.

Third, RDI sector: at the moment, in the Economic and Social conditions described above, the entire Romanian society has expectations of stimulating the technological transfer from this sector. From the perspective of the agricultural field, in Romania, it can be identified two categories of RDI organizations: the agricultural sciences and veterinary medicine universities, associated in the Consortium of the Universities of Agricultural Sciences and Veterinary Medicine in Romania, and the Academy of Agricultural and Forestry Sciences (AAFS), which conducts the research-technological development-innovation RDI activities in the agricultural field and coordinates R \& D institutions, national institutes, research-development institutes and research centers, experimental bases. The current AAFS structure includes nine scientific departments, coordinates seven national institutes, 11 branch institutes and 42 research centers [35].

Basically, after the abolition of Agricultural Production Cooperatives and State Agricultural Enterprises in 1990, in Romania, the only entities that can create new products, test and evaluate new products for commercialization are agricultural universities and AAFS, respectively [33].

Of course, the biggest promoter of technology transfer in agriculture should be AAFS and, within the limits of the funding it can access, it probably does. However, AAFS funding has been under-dimensioned over the past 25 years, resulting in massive depopulation of researchers in the field (from 2400 to 650), a decline in the number of R \& D-innovation units (from 112 to 60) [36] and, as a consequence, has led to a decrease in the capacity of the agricultural, agri-food and forestry system to meet the demands of economic operators, local and national public authorities (social demand) [37]. By comparison with the Romanian situation, in France, the French National 
Institute for Agricultural Research includes 180 laboratories and 49 experimental units in 13 scientific departments and 17 research centers, has an annual budget of 880 million EUR (77\% from the Ministry of Research and $20 \%$ of other public credits) and the human resource from agricultural research involves 12,000 specialists [35].

Waiting for better times for AAFS and for research in Romania, the agricultural sciences and veterinary medicine universities in Romania have an obligation towards the society to do their best in stimulating the transfer of technology through specific mechanisms, capitalizing on its third mission (along with education and research), namely the marketing of research outputs and involvement in socio-economic development. From this point of view, universities carry out a range of activities and market studies on different aspects, such as forms, stakeholders, drivers, barriers, benefits and impact, university technology transfer and entrepreneurship, contribution to regional development, government policies, aimed to strengthen University-Industry links, etc. These new activities endow students with new knowledge and entrepreneurial skills, which defines the University's entrepreneurship [30].

Similarly to universities in the USA and Western Europe, as found in the examples above, in Romanian universities, a large part of these activities are taken over by the TTO. Considering the information in the last paragraphs, TTO's responsibility in Romanian universities seems to be as big as the other sectors responsible for technological transfer less developed, and, at societal demand, we appreciate that it is enough to mention that Romania is a full rights member of the European Union.

Finally, since universities do not always have direct contact with the market, from the perspective of marketing the results, we appreciate the necessity to involve universities in various societal structures (associations, clusters, spin-offs, business companies) that bring the University closer to the societal needs and challenges, and to build bridges with society in identifying complex and mutually beneficial solutions (research oriented on solving societal problems).

Starting from the aspects outlined above, this paper aims to analyze the TTO activities to support transforming research outputs into commercialization in the context of the University of Agricultural Sciences and Veterinary Medicine from Cluj-Napoca, Romania (UASVMCN). Throughout this paper, different commercialization channels, the roles of technology transfer offices and multiple associative structures are further discussed with a special focus on agricultural open innovations and technologies. This study contributes to sustainable development of both Academia and agricultural Industry research, development and commercialization activities by illustrating current innovation and technology transfer activities produced by UASVMCN and its own TTO as a catalyst entity, a new model in Romania, so that the University-TTO-Economic partners association draw a functional and productive triple helix.

In this sense, the first objective is to analyze how the University creates added value (qualified human resource, innovative ideas, new products and services etc.) that can be harnessed to the benefit of the community. For this, it is relevant and will be exposed how the University invests in the capitalization of resources (human, material), new products and new services in agricultural fields through specific project management activities. The second objective of the study is to analyze how the University supports capitalizing its RDI outputs on the market, through specific services, but also through specific structures (associations, clusters, etc.), in which it is involved (technology transfer specific activities).

\section{Materials and Methods}

As far as Romania is concerned, in 2015, there were 36 accredited TTOs by the National Authority for Scientific Research and Innovation [38]. Temporary authorization and accreditation entities within the innovation and technology transfer in Romania are under Romanian legislation, namely GD No. 406 [39] and MO No. 5039 [40]. Unfortunately, their activity is poor and insignificant in terms of effective results, especially due to several factors: the lack of specific legislation in the field of technological transfer that allows the promotion and favoring of some activities and processes in this 
field, the poor financing of the specific activities of innovation, development and technological transfer, lack of successful internal models in the field of technological transfer. In addition, the Romanian literature describing the phenomenon is scarce.

For this reason, we have conducted a case study presentation of a Romanian TTO, operating on a Steinbeis model (a German model of technology transfer and open innovation) [6], within the University of Agricultural Sciences and Veterinary Medicine from Cluj-Napoca (UASVMCN), an agricultural applied university in the northwest Region of Romania. Thus, the main material used in the analysis consists of all the activities implemented within the university's TTO (called Center for Project Management and Technology Transfer-CPMTT) and the main results achieved, in the last 8 years and revealed in the CMPTT report [41].

Currently, UASVMCN is one of the most reputed universities in Romania. Nationally, it is part of the Consortium of Universities of Agricultural Sciences and Veterinary Medicine in the country and of the Cluj Universities Union. Internationally, UASVMCN is part of the European Universities Association, being evaluated by it in 2003. UASVMCN aims as a primary mission to promote excellence in education, advanced research, competitiveness, innovation and technology transfer through BA, Master's, Ph.D. and postgraduate academic training through a continuous educational track, advanced research and integration in a circuit of universal values in accordance with the requirements of a knowledge-based society, in order to strengthen the entrepreneurial university connected to the Economic and Social environment.

The methodology used in research aims to analyze the effects of implementing a new technology transfer model in a TTO in Romania, as a catalyst entity, based on a Steinbeis model (an Economic and Social management model that improves the general strategy of the institution in the field of technology transfer), to improve the potential of the TTO to generate technology transfer in UASVMCN, as an alternative to actual situation in Romania, respectively stimulating every teacher or researcher to develop his own abilities in economic management. The Steinbeis model proposes new catalyst research and development management structures (as TTO), which should limit the direct connection of Academia with Economy, facilitate and support the transfer between them, and finally fill the gap between these two worlds, in order to overcome cultural differences existing in Academia and Economy, to provide project management for each collaboration (projects) undertaken between the two parties and, thus, to increase the competitiveness both in Academia (research-innovation) and in the Economic area (development, market) (Figure 2).

\section{Advanced Technology Transfer Chain in Romania}

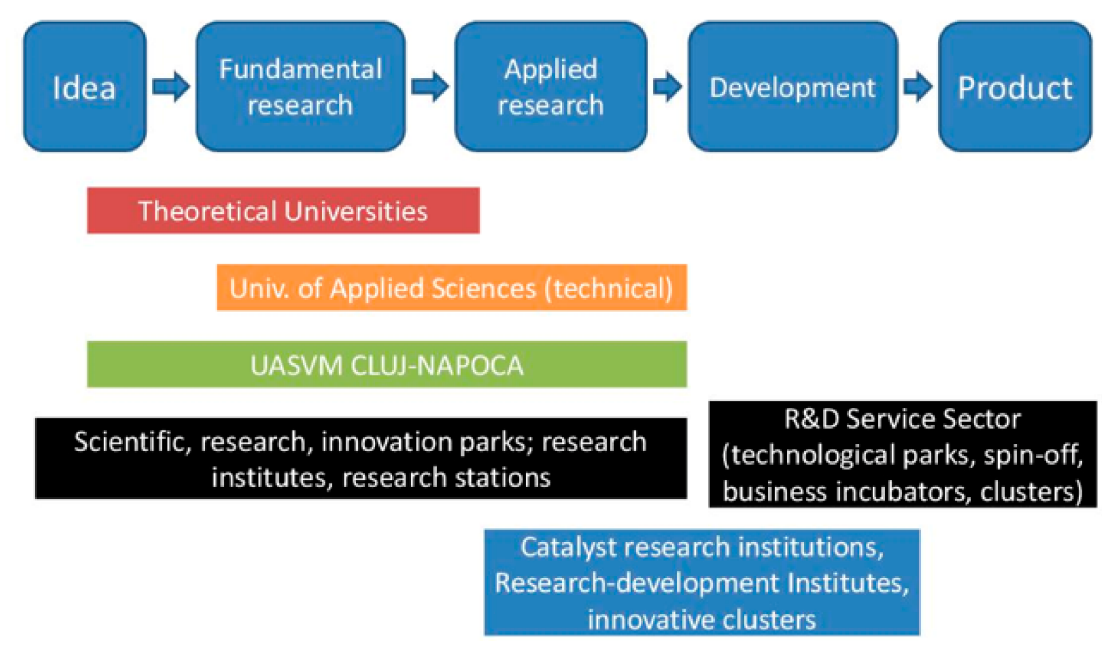

Figure 2. Advanced technology transfer chain model in Romania (future status). Source: [6]. 
Generally speaking, the types of technology transfer identified by this German model should cover: (a) funded projects; (b) research projects; (c) research contracts; (d) consultancy; (e) licensing; (f) spin-offs; and (g) company internships. Practically, the Steinbeis model supposes, for a TTO, to facilitate:

(a) developing the institutional capacity of the university through projects (funded projects, research projects) and an appropriate project management in order to provide technology transfer services and enable specific technology transfer activities: training of the educated and specialized human resources, the development of new products and technology services, supporting and promoting new patents, facilitating new research infrastructure, supporting spin-offs management, facilitating company internships, etc. and

(b) the development of specific technology transfer activities and the implementation of specific technology transfer projects in a triple helix system: implementing and/or facilitating research contracts, consultancy, or other specific services. These projects involve sounding the Economic and Social environment through specific market studies, on specific domains and using specific social structures, identifying solutions in mixed teams and implementing contracts accordingly.

Thus, the purpose and objectives formulated above are relevant to the TTO model experienced in the last 8 years in UASVMCN, for the first time in a university in Romania.

In this paper, we also analyze the context and the streams of work that facilitate the TTO to aid to the university's goals in order to become an entrepreneurial entity - an ecosystem that bridges research, innovation and business efforts. In order to assess the sustainability of using the above-mentioned TTO within an agricultural university, the methodological tools involving analysis are implemented. Thus, relevance, scoping, impact, comparative, associative analyses were conducted.

\section{Results and Discussion}

Common Agricultural Policy is the main policy framework that aims to support innovation in agriculture through farm training and know-how transfer [42]. Giannakis and Bruggeman [43] and Vecchione [44] highlight the important role of farm education and know-how transfer in farmers' ability to adopt technological innovation and the economic performance of the sector. TTOs can play a significant role here through the know-how transfer processes and uptake of farm-level innovations.

In Romania, adaptation to climate change responds to the need for conservation of natural resources and is therefore a priority for the Rural Development Strategy of Romania 2014-2020. Actions are needed to support the "accelerated" education and adaptation of farmers, processors and rural communities to climate change by improving sustainable water management and soil protection. This will also be supported by the transfer of knowledge, stimulating innovation and adapting research results to the real needs of the sector. It also aims to transfer farms from the older generations to young farmers, to rejuvenate the population working in agriculture and to educate and train young farmers, as they are the ones who can improve the productivity of agricultural holdings and increase access to the market [45].

On the other hand, Romania's National Competitiveness Strategy 2014-2020 [46] highlights as the main vulnerable point "weak links between research units and the business environment, low RDI (Research, Development, Innovation) spending (as a percentage of Gross Domestic Product), incipient connections at international level, reduced $\mathrm{R} \& \mathrm{D}$ results transfer, reduced demand for $\mathrm{R} \& \mathrm{D}$ by the private sector, and very low percentage of RDI employees in the active population".

Finally, the main directions of action of Romania's National Strategy for Research, Development and Innovation 2014-2020 are oriented towards the development of projects initiated by companies, competence centers, innovation infrastructure (business accelerators and incubators, technology transfer centers), doctoral and postdoctoral study programs in priority fields, national research infrastructure ("roadmap"), organizational performance and concentration, a strategic orientation mechanism [47]. 
According to national strategies described above, the vision of the CPMTT was geared towards implementing the strategy set by the European Council in Lisbon in 2000, to the recent alignment with EU policy guidelines, towards increasing capacity and competitiveness of university education and scientific research in accordance with the provisions of the 2014-2020 Romanian National Development Program, to their compatibility with similar systems in EU countries and to develop and intensify technology transfer between the University and the Socio-Economic environment.

CPMTT mission is to implement university's strategies and policies in education, research, development, innovation and technology transfer in terms of project management, in compliance with the dynamics of the national strategy of Ministry of Education and Scientific Research. The center also aims at developing and implementing the strategic objectives set at the governmental level, followed by the National Development Plan (NDP). It is envisaged especially the increasing role of scientific research and technological development in improving economic competitiveness and quality in higher education, in accordance with the requirements of integration into the European Higher Education and Research and the European Research Area (ERA).

CPMTT was established, on the one hand, to increase institutional performance and to improve the framework for access to national and international financing by projects, on the other hand to stimulate technology transfer between Academia and Socio-Economic environment, being a multi-, inter- and transdisciplinary center of technology transfer and business management of research and consulting.

From a project management activities perspective, CPMTT can draw the following synthetic cumulative results, resulting from the implementation of over 13 major projects [41]:

- Over 16 million EUR attracted to the university budget;

- Over 700 purchased and installed research equipment;

- Almost 50 new research laboratories, in addition to the about 200 previously existing ones;

- 323 Ph.D.s and postdocs trained in a field of applied research;

- 1760 scientific articles published in international databases (1663 BDI and 97 ISI articles);

- Over 400 presentations at national and international scientific conferences;

- Over 60 outgoing mobility within the EU in know-how transfer activities;

- Over 45 Ph.D.s employed one year after the project completion;

- Over 1200 students granted in company internships;

- 5 "Career Days" events (3941 Participants) and 7 "Open Doors" events (4420 Participants) to support the insertion of graduates in the labor market;

- More than 36 transnational partners.

The above results draw the concern of our TTO in increasing of specialized resources (human, material, financial, solid academic foundation), which are to be involved and will support the RDI and technology transfer future activities (according to TTO project management activities described above).

As a well-oriented catalyst entity between Academia and Economy, a well-defined TTO (as CPMTT) can be used (and sometime must be used) according to Austrian economist Schumpeter, as a revival of evolutionary economics, to increase the Economic area as a process of qualitative change driven by innovation, which the author defined as new combinations of existing resources [48]. In "The Theory of Economic Development" [49], Schumpeter, essentially keeping the focus on the Industry sphere, considered the entrepreneur as the main protagonist of the innovation-generating process and innovation as originating from business only. As a result, CPMTT's higher training and specialization actions, through various funding projects, of good specialists in "life sciences" area, and their endowment with entrepreneurial skills, increase the dynamics of open innovation through entrepreneurial approaches, both directly and in sustainable partnerships with the university.

In their study "Using the Quadruple Helix Approach to Accelerate the Transfer of Research and Innovation Results to Regional Growth" [50], with regard to the Continuing Education that an entrepreneurial university can provide, Cavallini et al. appreciated that special synergies can be reached if the training 
targets are actors of the industry sphere (i.e., industrial players). On the other hand, the review highlights the main roles of the triple helix spheres (i.e., Academia-Economy-Government) and quadruple helix sphere (i.e., Academia-Economy-Government-Civil Society) and of their actors involved in knowledge and innovation creation and exchange, the changing of focus of these roles, or functions, over time, and the relationships among the key operational elements of the models. In a regional development perspective (such is Romania), the triple helix model provides an analytical framework for understanding the role of each helix in generating innovation in a territory and offers policymakers an operational tool on the basis of which growth strategies and paths to a capitalist economy are set according to the adaptation of the model to the contextual conditions.

According to the same study, the characterization analysis of the three innovator types (i.e., advanced, medium, modest) across the whole population of European regions shows that the best pullers of innovation in advanced type are Industry, Civil Society and Innovation Interaction, while the structural performance of University and Government seem to be limited, although this finding possibly suffers from the poor representativeness of the indicators available for measuring the innovation performance of these two helices. When innovation (eco-)systems and their growth dynamics are approached by means of helix models and focused on Civil Society engagement, the innovation performance of each region strictly depends on the relevance and development of each sphere as well as on the strength of interaction among them. The quantitative results of CPMTT presented above and graphic illustrated in Figure 3 below are a real measure of UASVMCN's involvement in basic education, in continuing education, in applied research, in sharing knowledge and transfer of know-how, in University-Industry collaboration or in University-Civil Society collaboration, to prove the entrepreneurial feature of our university.

Among the most relevant and productive laboratories (in relation to the market), we have to exemplify genetics and amelioration laboratories (which produce new agricultural and horticultural species), terrestrial measurement and cadastral laboratories (contributing new services to the development of precision farms), pilot experimental stations (for new milk, meat, flour, beverages, or sweets products), or gene bank (a unique facility in Romania that stores vegetal and animal genes in three distinct ways: in vivo, in vitro and through cryo-storage).

The significant results are illustrated graphically below (in terms of human resources involved-Figure 3, respectively, from the financial perspective-Figure 4). The lack of significant research results in 2013 is due to the lack of grants funding the research over the period, which once again reflects the importance to fund the research area in order to bring added value accordingly. In addition, Mr. Alfred Oberholz, chairman of DECHEMA-Gesellschaft Deutscher Chemiker (an important Steinbeis partner) stated that "Research turns money into knowledge; innovation turns knowledge into money".

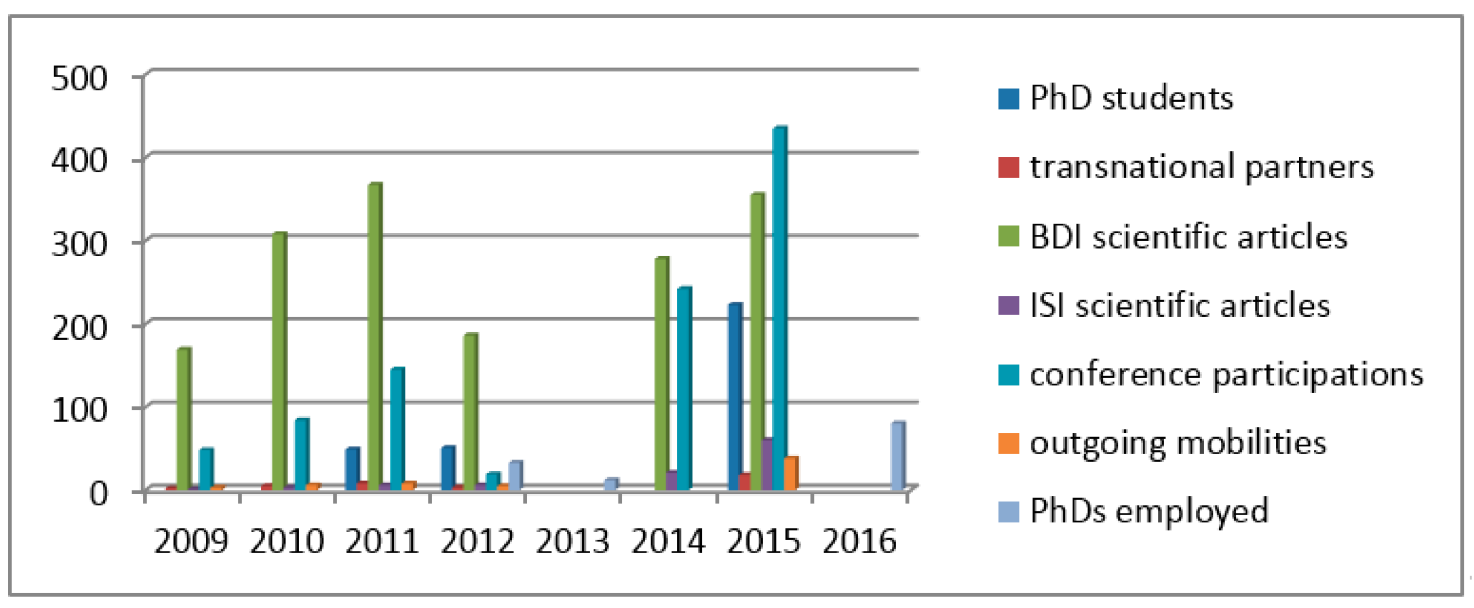

Figure 3. Human Resources management by CPMTT. Source: authors processing. 
In the next graphic, the financial results from grants (research public funding) are compared with the total revenues of the university in the last eight years (the grants are included in total revenues below). The financial data are part of the university's financial reports published each year by the Ministry of Finance of the Government of Romania.

All of the indicators presented above demonstrate an important contribution to the sustainable development of the university on several levels: infrastructure for research, development, innovation and technology transfer, research equipment, qualified human resources management, research results, partnerships and mobility, insertion of skilled work force in the labor market-especially in rural areas (in the Economic and Social environment), services offered for the Economic environment and smart specialization area ("bioeconomy" as a whole), as they are defined in European, respectively, in Romanian legislation [47,51].

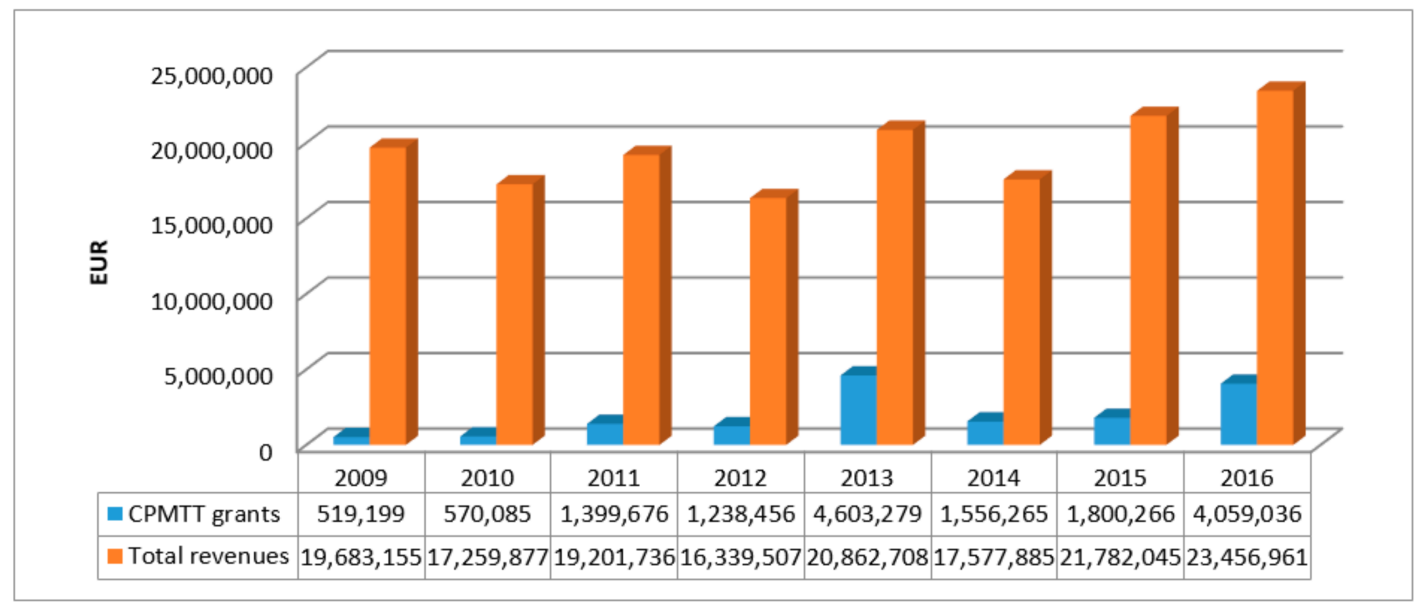

Figure 4. Financial Management of grants by CPMTT. Source: authors processing.

As a consequence of the project management activities and the results obtained and presented above, the new young researchers supported by the CPMTT projects, in the period of 2012-2016, have generated and applied over 500 new research, development, innovation and technology transfer projects (Romanian and European funding), proposing over 500 new products or services in all the agricultural fields in which they were trained. In this sense, the European Commission aims to improve the transfer of research knowledge and results in intended users in Horizon 2020 projects, by identifying the technology readiness level (TRL) towards commercial use of proposed research products [52].

Unfortunately, the lack of adequate funding of research in Romania, poor experience of our universities in drawing Horizon 2020 projects and high competition on the RDI projects market makes over $80 \%$ of these results to remain only at the laboratory certified study level (TRL 2-technology concept formulated, TRL 3-experimental proof of concept, or at most TRL 4-technology validated in lab). On the other hand, over $80 \%$ of those funded are patented directly by companies (university's project partners in application grants, usually SMEs), due to the faulty way in which internal funding guidelines are thought to be made, leaving both the university and its researchers (the inventors, innovators) without the proper use of their work and their involvement. Anyway, at this stage, the products or the services are only certified at the TRL 5 level-technology validated in relevant environment (industrially relevant environment in the case of key enabling technologies), or at the TRL 6 level-technology demonstrated in relevant environment (industrially relevant environment in the case of key enabling technologies) [53].

Specifically, the most important funding line for patents in Romania is "Innovation Checks", financed through the state budget. In accordance with the provisions of the financing guide, the beneficiary of an innovation check must be an economic company (and not a research institution!) 
that needs just a partnership agreement with a research institution, from which it takes over the innovative product or technology and, for the amount of $€ 10,000$, patented it in its own name! Therefore, the institution (the university) is rewarded for innovative ideas and products, but the patents that result belong to a company in the economic environment! (as presented in Figure 5 below). We consider it a serious error of the state policy, but it is still our legislation. Furthermore, in the absence of financing and any other real motivation, university researchers no longer provide support for refining products to market impact, and these patents often remain unleashed on the market, or disappear very easily in the fight with market competition.

Figure 5 below presents the concrete situation of UASVMCN licenses (innovation patents) and academic awards of the last eight years.

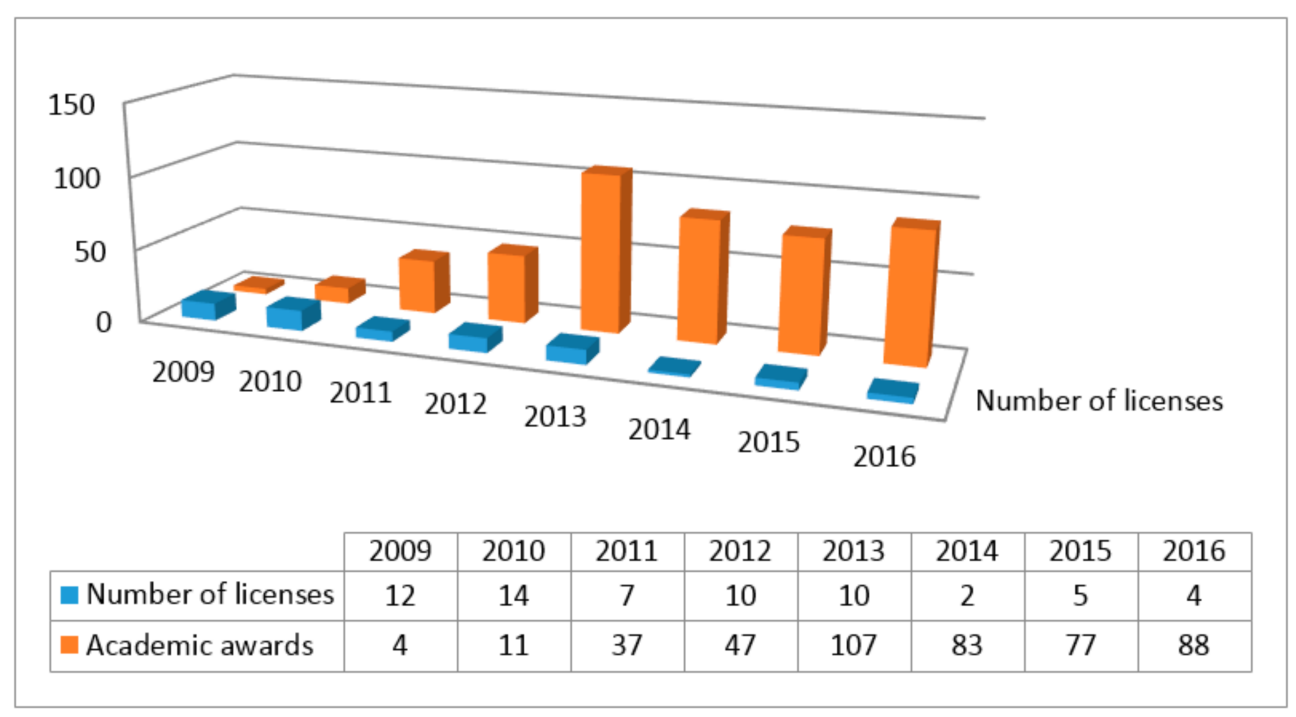

Figure 5. Number of licenses and academic awards. Source: authors processing after [54].

Figure 5 also demonstrates the evolution of academic awards in the last eight years that clearly proves that UASVMCN investment through CPMTT activities definitely contribute to the increasing of RDI marketable results. Finally, innovative products or technologies created in the university and tested in the laboratories or experimental fields of the university, which have managed to overcome all barriers and cross all stages of development, are commercialized in business through the UASVMCN-TTO-SMEs triple helix, bringing economic benefits to both the Economic environment (including agriculture area) and the University-a few examples: new species of flowers, plants and fruit trees, new products derived from milk, meat, vegetables and fruits, agricultural and rural development consultancy services, medical services.

Thus, from the perspective of UASVMCN, the problem in linking the structural conditions of Romanian agriculture with technology transfer process using TTOs is not so much the development of new products or new technologies, but more the lack of funding and lack of strategies in the field of technology transfer to disseminate and real transfer the knowledge in the field. As a public university, UASVMCN cannot entirely cover the lack of funding (still, there are limited internal grants to stimulate and increase the transfer of knowledge from our university to business), but, using its TTO (CPMTT) and the right strategies (Steinbeis model), it is possible to increase the level of knowledge transfer, the capacity to commercialize the products and services and thus to contribute both to solve societal needs and to improve the agriculture in Romania.

The technology transfer activity is a more recent concern of CPMTT, started from the necessity of linking the university to the demands and realities of the Economic and Social environment in order to gain the status of an entrepreneurial university, in full agreement with the strategies of other international universities and also with Steinbeis model ("Technology transfer facilitate and speed 
up innovation", as state Mr. Hugo Hammerle, manager of Natural and Medical Sciences Institute at the University of Tubingen, an important Steinbeis partner).

Nowadays, the technology transfer process should be understood in open innovation dynamics under Schumpeterian Evolution Economics, from Schumpeter concepts of innovation and economic development (1911) to quadruple helix (2009) [50]. Open innovation is an innovation framework proposing that established firms use external sources as pathways to new ideas, technologies, business models and markets. Within this framework, established companies can use startups, or young, growth-oriented business to help them achieve radical or breakthrough innovations. A Schumpeterian view on the diversity of technological change allows for disentangling the specificities and effects of innovation inputs and outputs, and of new products and new processes. A structural change perspective on the role of demand as a driver of innovation and on the importance of open economies allows for linking industries' dynamics with international competitiveness. A business cycle perspective crossing the two previous approaches sheds new light on the fragility of key economic relationships and on the long-term damage that recessions may cause to the 'virtuous circle' of innovation and performance [55].

On the other hand, open innovation creates an inverted U-curve performance with a high-level fluctuation complexity according to three major factors: knowledge intensity, open innovation strategy, and time span. The impact of open innovation on business performance is very dynamic and appears in unpredictable forms [56]. Nevertheless, in the context of "knowledge capitalism", universities become the means of competition for global leadership in the high technologies [57]. Analyzing our university results presented above and graphics illustrated in Figures 3 and 5, related to Schumpeterian Dynamics of Open Innovation and according to the three factors mentioned above (i.e., knowledge intensity, open innovation strategy, and time span), we really could appreciate that, in the future, we could attend to conquering the growth limits of capitalism (from agricultural perspective) by innovating high technologies in the "life sciences" area (e.g., Smart Agriculture based on IT solutions, sensors, robotics, digital economy, food safety, circular economy, renewable energy, telemedicine, etc.).

The theory of complex adaptive systems, when applied to the Economic and Social domain, has enabled a few authors to confront the distinction between knowledge and the institution of Social understanding. They mapped the difference between knowledge, which is private, and understanding, which is Social. If knowledge is a characteristic of individuals, understanding then becomes an emergent phenomenon arising from the interaction between individuals in specific contexts. Understanding has boundaries, it has components that possess great heterogeneity, and is sustained by the connections of information flow. It is a socially distributed process whose growth is dependent on a systemic context, on the way a given set of individuals interacts to share information and thus to further develop their idiosyncratic knowledge. Recognizing that understanding is necessarily distributed leads to the insight that economic activity, which is necessarily Social, depends on shared understandings, that is to say, correlated knowledge. This provides a clue as to the unpredictability and unevenness of knowledge accumulation, and, of course, the unpredictability of capitalism as a knowledge driven system [58], with all the expansion of European capitalism, based on hierarchical relationships between societies, and its distinctive social-ecological systems over the past five centuries [59].

In the spirit of these modern technological transfer concepts, through CPMTT, UASVMCN is involved in all the Social and Economic structures (associations, clusters, etc.) that have the potential of technology transfer and that cater to smart areas (especially "bioeconomy" in rural areas), where added value is viable, or where it can aid to the community [41]. In our view, the final goal of the associations and clusters is to create synergies, set collaborations, and open innovation opportunities between $\mathrm{R} \& \mathrm{D}$ organizations and national (even European) public and private stakeholders dealing with different modern concepts that our university is able to manage (social inclusion in complex innovation eco-systems, smart agriculture using IT solutions, renewable energies, smart city based on "life sciences" approach, dynamics of open innovation and technology transfer eco-systems based). Activities carried 
out in these associations and clusters are focused on information exchange, education, integration of multiple stakeholders' needs, and provision of support on relevant regulation and legal frameworks related to the market in Romania. Among these, we mention:

- Regional Institute for Research, Education and Technology Transfer (RIRETT)—UASVMCN was a founding member - this was the first research institute in the Northwest Region of Romania and includes universities, research centers in the region, and public administrations. The institute is coordinated by Northwest Regional Development Agency and implements research and technology transfer projects financed from European funds;

- Northwest Regional Pact for Employment and Social Inclusion Association (NW RPESIA)—UASVMCN was a founding member and is a member in the board of directories-this is the most important Northwest Regional social organization that implements social projects for the society. UASVMCN focuses on facilitating insertion of its graduate students in the labor market, especially in rural areas. In partnership with this organization, UASVMCN identifies global sources of funding, through which develops further Entrepreneurial Competences for selected students, helps them to create performed business plans, sometimes provides funding for their start-up and advises this start-up during the implementation of the business plans to ensure business success and adding value to the young entrepreneurs in rural areas. To develop competencies associated with innovating in an interconnected technologically flat world, some authors recommend a training course of Designing for Open Innovation designed to empower 21st century engineering students, taking the advantage of emergence for complex innovation eco-systems, managing but not solving dilemmas associated with innovation [60]. On the near future, this course should be a real needed one for all of the Romanian universities to improve open innovation in technology transfer processes;

- Cluj IT Cluster-UASVMCN was a founding member and is a member in the board of directories-this is the biggest IT cluster in Romania and also in Eastern Europe. Today, the world crosses the most important technological revolution based on automating and digitizing processes through advanced technologies. Agriculture cannot be a silent witness to this revolution. It is clear to everyone that modern agriculture should be based on new concepts such as Smart Agriculture and Internet of Things. As a member of this cluster, the university secured the most competent IT partner to help achieve and implement these concepts. Among the most important projects that the university is working on in this regard, we can mention: connecting and integrating the family farms to the value chains; automating and digitizing of the technological processes in agriculture, using special equipment (such as sensors) and special software to monitor, control and remote control. All of these prototypes are tested in experimental fields of the university (greenhouses, resort teaching and research, vegetable farm and livestock farm) and then they are multiplied in business;

- AGRO-FOOD IND NAPOCA CLUSTER (AFIN Cluster)—UASVMCN was a founding member and is a member in the board of directories-this is the most important value chain organization for the farmers, especially in the field of food processing. In this period, AFIN Clusters and UASVMCN are implementing a new European project: “AgroTransilvania Cluster-innovative cluster specialized in the field of bioeconomy-INOV.BIO-EC" (2014-2020 Competitiveness Operational Program, 2016-2020 implementation period, about EUR 4 million of European grant)-UASVMCN plays an important role by using its pilot stations mentioned above to plan, process, analyze, control and certify the quality of the food, using traditional recipes and working directly with the farmers;

- TREC CLUSTER-Transylvania Energy Cluster-UASVMCN was a founding member and is a member in the board of directories-also plays an important role in renewable resources management, especially biomass. UASVMCN holds significant resources of biomass (energy crops, fruit draff, meals, manure), which can be used to produce renewable energy using new technologies and competent partners in the field of clean energy, so connecting corporations 
and communities. At the same time, using these modern technologies, we contribute to the protection of the environment. Despite strong forces, both within and beyond clean-tech clusters, for maintaining neo-liberalized approaches to clean-tech activity, it is concluded that, for as long as clean-tech clusters remain open and inclusive of actors proposing alternative pathways, they do represent potential, albeit provisional, assemblages for transformation [61];

- Cluj Innovation City Foundation (CIC Foundation)—UASVMCN was a founding member and is a member in the board of directories - this is the most important "smart city" concept that Romania holds at this moment. In the last five years, European Commission encouraged the development of several smart cities concepts through funding and partnerships, due to the increasing demand for innovation in usual activities that could be achieved by technology transfer processes, allowing people to directly contribute at the development of an inclusive society based on open innovation, for a better quality of life. To achieve better results, one of the latest evolutions within smart cities projects is the implementation of Living Labs (LLs). A research conducted by Bifulco et al. [62] on the three top smart cities in Europe-i.e., Amsterdam, Barcelona and Helsinki underlined the importance of the open and ecosystem-oriented approach for smart cities, showing the fundamental role of universities in teaching how to manage relationships in LLs and in promoting a culture of open innovation based on citizens and making the city an open laboratory. The key results are related to creativity, innovation, culture, and knowledge. Because it is an applied university in the field of "life sciences", UASVMCN plays a central role in the implementation of the smart city concept based on LLs in our region, assuming responsibility for creating, innovation and maintenance of living systems that contribute both to the preservation of a clean environment, as well as to the development of an entrepreneurial education and culture based on living products and technologies (according to the Latin dictum "mens sana in corpore sano"). Through this approach, CPMTT brilliantly combines more benefits for the university: it contributes to the development of a society based on knowledge but also on the appreciation of life (Social role), broadens its research perspectives and reduces the institutional risk of integrating graduates into the labor market (Academic role) and contributes to the development of the Economic environment through successful entrepreneurial approaches (Economic role), demonstrating its mission of the catalyst in triple helix. This also could be an undeniable pattern of measuring synergy in open innovation systems, by appreciating each complementary feature Academic-Societal-Economic involvement in the triple helix;

- Danube Transfer Centre-center for innovation and technology transfer initiated and coordinated by Steinbeis Europa Zentrum from Germany at the request of the European Commission, to improve technology transfer process and promoting dynamics of open innovation in Central and Eastern Europe-this is a huge network of partners (about 1000 Steinbeis centers around Europe) helping to develop open innovation and technology transfer processes both in Romania and in Central and Eastern Europe. The presentation made by Steinbeis officials at the 6th Annual Forum of the EU Strategy for the Danube Region [63] noted the increase of funds used in 2011-2017 open innovation projects from an initial budget of 200,000 euros to approx. 6.5 million EUR, which proves real dynamics from open innovation to evolutionary change.

Summarizing, the involvement results of the university in smart specializations identified above is illustrated in the graphic below (Figure 6).

Especially for rural areas, CPMTT provides at least the following types of services:

(a) Develop strategies of rural and regional development: impact studies and diagnostics for building development strategies to local, rural, regional or sectoral, based on analysis of the needs, resources and trends;

(b) Development of marketing strategies for marketing products in rural areas: analysis of producers, consumers, business, competition and market realities and trends to create marketing mix. 
From this perspective, as an active participant in the production and distribution services, the client is a productive factor, formative of the quality, value and satisfaction [64];

(c) Impact studies on economic and financial activity: analysis of financial statements in terms of specialized indicators to give a realistic image of the financial-economic activity and possible interventions to improve;

(d) Studies on strengthening local food markets in rural areas and the development of short supply chains: fostering services to support local producers to develop local markets trading local food products and some food products;

(e) Studies on socio-economic development in rural areas: counseling and support in creating, managing and interpreting nature sociological studies and research on the development of economic activities in rural areas;

(f) Business plan for establishment/business development in rural areas (agriculture, agro-tourism, businesses in rural areas): advisory and management consulting services to base business plans and successfully to implement and monitor them;

(g) Developing skills in entrepreneurship: offering theoretical and practical skills and professional skills in areas related to entrepreneurship. A special role should be played by social entrepreneurs, who are different from business people by taking on a Social mission that is more important than making profit for shareholders, associates or owners [65].

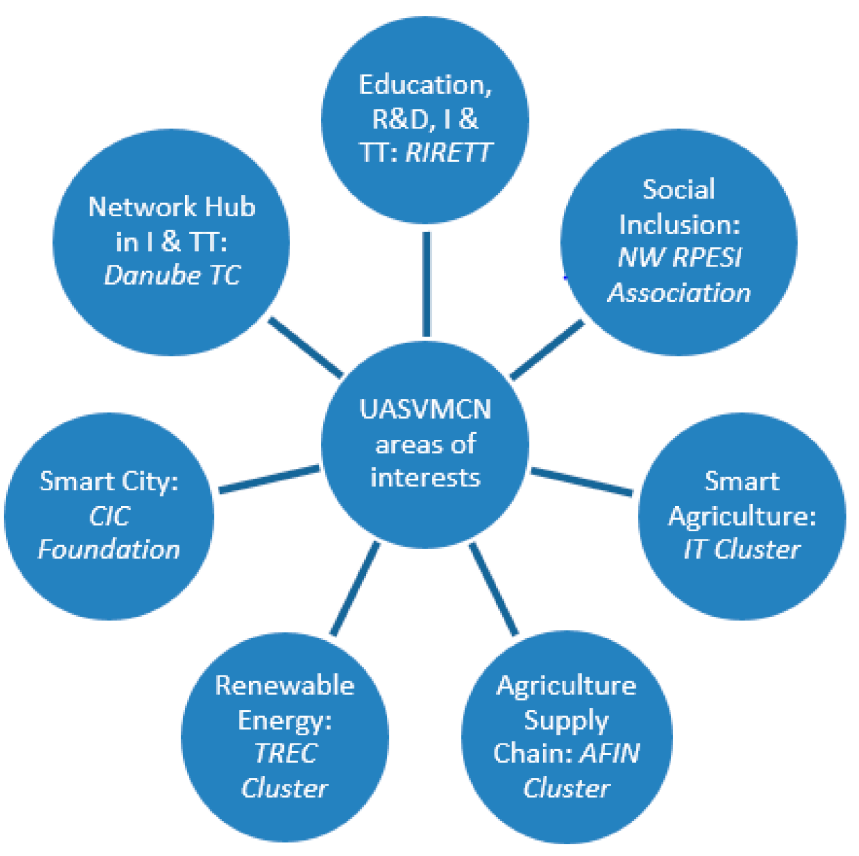

Figure 6. The UASVMCN involvement by smart specializations. Source: authors processing.

Figure 7 below shows the situation of UASVMCN research and economic contracts in the last eight years.

Last but not least, as a catalyst entity, the CPMTT is involved in all projects carried out in partnership by universities and companies (e.g., the partial financing of students internship to the companies), to ensure effectively the triple helix and open innovation effect, getting involved in project management, in relation to the market, in preparing documentation on intellectual property, in networking and matchmaking or in provision of any other specific innovation and technology transfer services. Recent studies in Korea show that there were differences in the distance and open innovation among Fortune 500 firms, Fortune non-500 firms, laboratories, universities, and start-ups. Thus, there are relations between the distance between technology and the market, 
and open innovation. The same studies indicate that the distance between technology and the market was found to moderate the open innovation effect in Fortune 500 companies and laboratories [66].

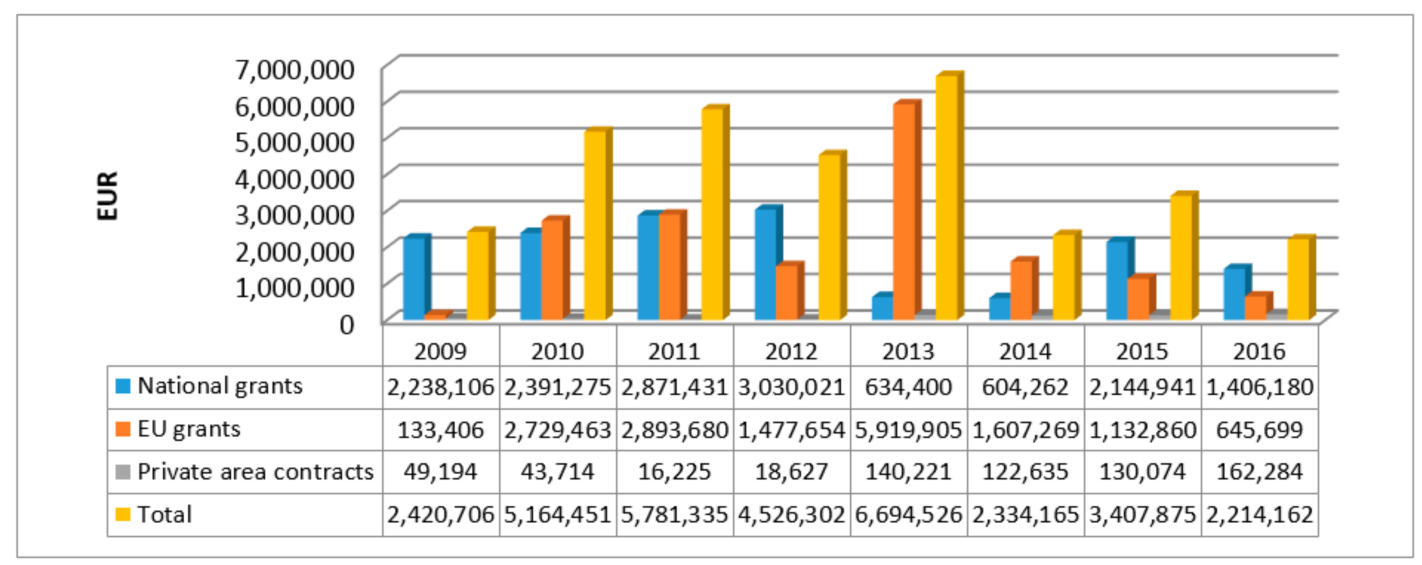

Figure 7. The RDI and technological transfer contracts of UASVMCN. Source: authors processing after [54].

The recent CPMTT's projects and activities have proven to be effective and efficient in facilitating and developing technology transfer, whether we talk about studies and analyzes on the correlation of university curricula with the requirements of the Socio-Economic environment (studying and applying new technologies, alignment to new standards, etc.), the testing and implementation of smart precision farming concepts (the use of sensors in experimental greenhouses, storage in cloud and other Internet of Things concepts with multiplying effect in business) or the provision of various other services in innovation and technology transfer.

\section{Conclusions}

First, from the all activities performed within a TTO, several communication barriers (cultural differences) can be observed between actors from the Academia and the Economic environment (Figure 8).

\section{Cultural differences in Research and Business}

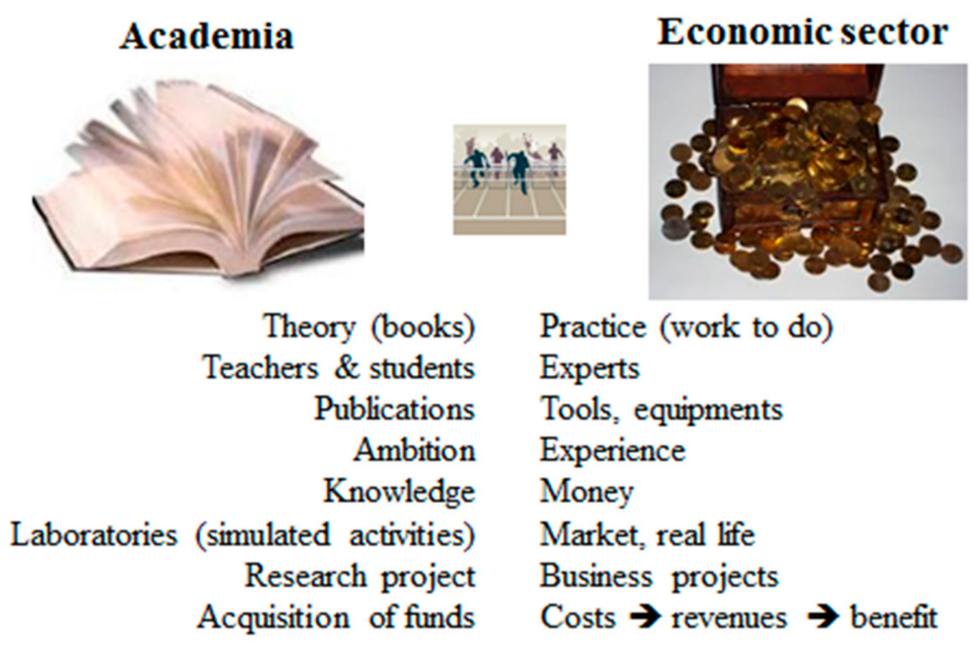

Figure 8. Communication barriers (cultural differences) between Academia and Economic. Source: authors processing. 
We consider that these barriers are natural, based primarily on formation/deformation of each professional and psychological profile developed over time, strongly influenced by the characteristics of their own work environment. These barriers cause communication and understanding errors, which ultimately affects the progress of technology transfer projects and translates into a higher consumption of time and/or money, or even the failure of output or outcome assumed indicators. From the experience of the projects implemented within the CPMTT and the effects propagated by them at the institution level (improving the mentality and education of our researchers through training and improvement projects in order to maximize their efforts and yields on their areas of competence, and the use of TTO as a catalyst institution in triple helix, their individual remarkable results, but also by the institution-at a general level), as well as from the experience of the technological transfer activities (involvement of the institution through associations and clusters, through specialized technology transfer services, in solving societal problems, especially in the field of agriculture), we state that a well-defined TTO facilitates communication between the two environments players, making the activities compatible each other and ensuring to achieve that all the indicators undertaken within the project and maximizing the impact in the Social and Economic environment.

On the other hand, in terms of money (budgets achieved), the existence of a TTO does not affect the direct interaction of researchers with the business, but only facilitates this process, bringing additional revenue and guarantee the achievement of all activities, avoiding divergence between expectations and effective achievements. Particularly, in the case study presented above, it has resulted that, through his work, TTO contributed about $15 \%$ to the annual university budget and the estimates for coming years are for a contribution of approximately $25 \%$ to the university budget. Obviously, these contributions are directly proportional to the level of involvement of the university in supporting the TTO team. Indirectly, by stimulating the creation of new products and services that are commercialized on the market, which are separately quantified and benefit over time, the use of the Steinbeis model in organizing a TTO greatly contributes to the valorization and commercialization of research results, to the material and immaterial capitalization of the institution, in order to stimulate entrepreneurial spirit among researchers and society, defining the entrepreneurial character of the university.

Regarding the diversity of the grants, it is absolutely easy to observe that a TTO is equidistant from all areas of specialization of the University and does nothing else but to identify its real needs and to find solutions for each one, based on a hierarchy of priorities that is part of the University's strategy. Granted, a TTO can be involved (and must do it) in solving the global needs of the University, such as new research infrastructures, doctoral and postdoctoral scholarships, increasing the quality of education, literacy, entrepreneurship, or equipment facilities to ensure their joint operation by as many researchers is needed-all these areas fully contribute to the sustainable development of the University. In particular and, additionally, TTO apply consistently the development strategies based on smart specialization areas (especially "bioeconomy"), even whether it affects the particular expectations of some researchers.

Last but not least, as can be observed from the results presented above, acting as a catalyst entity in the triple helix, a well-defined TTO can support innovation, promote new products and technologies, facilitate the commercialization of the research outputs on the market, and generally can improve the entire technology transfer process by all the channels (project management, services, associative structures), thus contributing to both Academic and agricultural Industry research-development-innovation and proving the benefits of the triple helix in solving the societal demands. In fact, including Civil Society in its preoccupation, by solving societal demands and involving Civil Society in open innovation eco-systems, a well-defined TTO can also bring and prove its benefits even in quadruple helix as well, which is the reference approach for the preparation and implementation of Research and Innovation Strategies for Smart Specialization [51].

Still, the legislation and working procedures in Romania in the field of RDI and technological transfer need to be more predictable and must be updated, so that the work and results of researchers and universities could be better capitalized in the Economy, the Academia-Economy relationship 
could be improved, and this will be reflected in the evolution of technology in agriculture and in the welfare of the population (for example, Romanian legislation does not yet define the terms of spin-off, innovative cluster or open innovation, there are no specific rules for their operation and this needs to be resolved as soon as possible; consequently, a number of clusters operate in Romania according to a European model adapted to Romanian associative forms, but in the spin-off field there are no significant examples). In addition, comparing the Steinbeis model with other models presented above (for instance, the CDC model), we also appreciate that applying the Steinbeis model in a TTO must be improved by providing patenting and licensing services to the researchers, in order to protect their innovations.

Given the achievements presented above, we state that the establishment and right operating of a TTO within a University is a real opportunity for the University and the activity of the TTO could be easily diversified, both from the perspective of an alternative to research funding, education, literacy or entrepreneurship, and from the cultural perspective of the University correlation to the current trends in RDI and technology transfer, on a unique and entrepreneurial European market.

Acknowledgments: The authors are grateful to Steinbeis Europa Zentrum, Karlsruhe, Germany, for coping with our university in the DTC Network and for supporting us in all the efforts needed to implement an efficient new model of open innovation and technology transfer.

Author Contributions: All authors contributed equally to this work (C.S.V. as manager of CPMTT and A.F. as support counseling of CPMTT), read and approved the final manuscript.

Conflicts of Interest: The authors declare no conflict of interest.

\section{References}

1. Stevens, A. The Enactment of Bayh-Dole. J. Technol. Transf. 2004, 29, 93-99. [CrossRef]

2. Ramanathan, K. The polytrophic components of manufacturing technology. Technol. Forecast. Soc. 1994, 46, 221-258. [CrossRef]

3. Phillips, R. Technology Business Incubators: How Effective Is Technology Transfer Mechanisms? Technol. Soc. 2002, 24, 299-316. [CrossRef]

4. William, F.; Gibson, D.V. Technology Transfer: A Communication Perspective; Sage: Beverly Hills, CA, USA, 1990.

5. Mittleman, J.H.; Pasha, M.K. Out from Underdevelopment Revisited: Changing Global Structures and the Remarking of the Third World; St. Martin's Press: New York, NY, USA, 1997.

6. Vac, S.C.; Vac, L.M.; Nas, L.V. Research, innovation and technology transfer in agriculture. B Uasvmcn. Agric. 2015, 72, 251-262.

7. The Association of University Technology Managers, Cité dans Conseil de la Science et de la Technologie du Québec, Chaînes de Valorisation de Résultats de la Recherche Universitaire Recelant un Potentiel D'utilisation par une Entreprise ou par un Autre Milieu. 2006, p. 7. Available online: http:/ /www.autm.net/ (accessed on 30 November 2016).

8. Hague, D.; Oakley, K. Spin-Offs and Start-Ups in UK Universities; Committee of Vice-Chancellors and Principals (CVCP) Report; Universities of the United Kingdom: London, UK, 2000.

9. Allen, T.J.; O'Shea, R.P. Building Technology Transfer within Research Universities—An Entrepreneurial Approach; Cambridge University Press: London, UK, 2014.

10. Madies, T.; Guellec, D.; Prager, J.-C. Patent Markets in the Global Knowledge Economy_Theory, Empirics and Public Policy Implications; Cambridge University Press: London, UK, 2014.

11. Von Ledebur, S. Technology transfer offices and university patenting-A review. Jena Econ. Res. 2008. Available online: http:/ / zs.thulb.uni-jena.de/servlets/MCRFileNodeServlet/jportal_derivate_00115987/ (accessed on 15 April 2017).

12. Centers for Disease Control and Prevention. What Is the Process of Technology Transfer? 2016. Available online: http:/ /1.usa.gov/1NkBW7a (accessed on 10 April 2017).

13. Blohmke, J. Technology complexity, technology transfer mechanisms and sustainable development. Energy Sustain. Dev. 2014, 23, 237-246. [CrossRef]

14. Abrams, I.; Leung, G.; Stevens, A. How are U.S. Technology Transfer Offices Tasked and Motivated?-Is it all about the Money? Res. Manag. Rev. 2009, 17, 1-34. 
15. Conti, A.; Gaule, P. The CEMI Survey of University Technology Transfer Offices in Europe; CEMI Report; École Polytechnique Fédérale de Lausanne: Laussane, Switzerland, 2008.

16. Conti, A.; Gaule, P. Are the US Outperforming Europe in University Technology Licensing? A New Perspective on the European Paradox; CEMI-WORKINGPAPER-2009-003; Institute of Management and Technology: Laussane, Switzerland, 2009.

17. Porter, M.E. The Competitive Advantage of Nations; The Free Press: New York, USA, 1990.

18. Asheim, B.T.; Coenen, L. Knowledge bases and regional innovation systems: Comparing Nordic clusters. Res. Policy 2005, 34, 1173-1190. [CrossRef]

19. Chaminade, C.; Vang, J. Globalisation of knowledge production and regional innovation policy: Supporting specialized hubs in the Bangalore software industry. Res. Policy 2008, 37, 1684-1696. [CrossRef]

20. Belussi, F.; Sedita, S. Localized and Distance Learning in Industrial Districts. Business Networks in Clusters and Industrial Districts: The Governance of the Global Value Chain; Routledge: Abingdon, UK, 2010.

21. Marklund, G.; Nilsson, R.; Sandgren, P.; Thorslund, J.G.; Ulstrom, J. The Swedish National Innovation System 1970-2003: A Quantitative International Benchmarking Analysis; Vinnova Analysis: Stockholm, Sweden, 2004.

22. Parrilli, M.D.; Aranguren, M.J.; Larrea, M. The role of interactive learning to close the "Innovation Gap" in SME-based local economies: A furniture cluster in the Basque country and its key policy implications. Eur. Plan. Stud. 2010, 18, 351-370. [CrossRef]

23. Clark, J. Coordinating a conscious geography: The role of research centers in multiscalar innovation policy and economic development in the US and Canada. J. Technol. Transf. 2010, 35, 460-474. [CrossRef]

24. Liege University-Technology Transfer Office as a Company-University Interface. Available online: $\backslash$ unhbox \voidb@x \hbox\{http:/ / bit.ly/2mGyhUL\} (accessed on 16 April 2017).

25. Wageningen University and Research Centre-The Centre for Development Innovation. Available online: http:/ / bit.ly/21PE21B (accessed on 16 April 2017).

26. Research Support, Innovation \& Technology Transfer Unit of Boku University of Natural Resources and Life Sciences, Austria. Available online: http:/ / bit.ly/2rhEto5 (accessed on 10 June 2017).

27. Navis, C.; Glynn, M. Legitimate distinctiveness and the entrepreneurial identity: Influence on investor judgments of new venture plausibility. Acad. Manag. Rev. 2011, 36, 479-499.

28. O'Kane, C.; Mangematin, V.; Geoghegan, W.; Fitzgerald, C. University Technology Transfer offices: The search for identity to build legitimacy. Res. Policy 2015, 44, 421-437. [CrossRef]

29. Bozeman, B. Technology transfer and public policy: a review of research and theory. Res. Policy 2000, 29, 627-655. [CrossRef]

30. Stanford University-The Triple Helix Concept. Available online: http://stanford.io/2u03uZU (accessed on 8 July 2017).

31. KeysFin-Business Study in Romania. Available online: http:/ / bit.ly/2sDW5w4 (accessed on 8 July 2017).

32. National Institute of Statistics in Romania-Agriculture, Forestry and Fishing. Available online: http://bit.ly/ 2sMukUk (accessed on 8 July 2017).

33. Romanian Center for European Policies-Education for Agriculture. Available online: http://bit.ly/2u6CkBK (accessed on 8 July 2017).

34. Ministry of Agriculture and Rural Development from Romania-Innovation and Knowlwdge Transfer. Available online: http:/ / bit.ly/2u09jqu (accessed on 9 July 2017).

35. Academy of Agricultural and Forestry Sciences from Romania-Organization and Operation Rules. Available online: http:/ / bit.ly/2uYE5gz (accessed on 9 July 2017).

36. Master, F.P. Romania-Reorganization of Agricultural Research in Romania: Geostrategic Analysis. Available online: http:/ / bit.ly / 2u6BW5U (accessed on 9 July 2017).

37. Academy of Agricultural and Forestry Sciences from Romania-Swot Analysis of Agroecosistem Opportunities of Romania in the Field of Agricultural and Silvic Activities and Agricultural and Silvic Research. Available online: http:/ / bit.ly /2uFkYJe (accessed on 9 July 2017).

38. National Authority for Scientific Research and Innovation, Technology Transfer Entities Accredited Registry. Available online: http:/ / bit.ly/1Y5rcvx (accessed on 18 April 2017).

39. Romanian Government, Government Decision nr. 406/2003-Specific Approving the Methodological Norms on the Establishment, Operation, Evaluation and Accreditation Entities Within the Innovation and Technology Transfer and how to Support Them. Available online: http://bit.ly/2rrT9mo (accessed on 18 April 2017). 
40. Romanian Government, Ministerial Order nr. 5039/2003 of the Minister of Education, Research and Youth, Approving the Procedure on Accreditation Entities within the Innovation and Technology Transfer. Available online: http:/ / bit.ly/2rrWhOZ (accessed on 18 April 2017).

41. Vac, S.C. CPMTT Report 2016, Strategy and Description. UASVM Cluj-Napoca. Available online: http:/ / bit.ly/24zAhyI (accessed on 18 April 2017).

42. European Commission. Council Regulation (EC) No 1305/2013; European Union: Brussels, Belgium, 2013.

43. Giannakis, E.; Bruggeman, A. The highly variable economic performance of European agriculture. Land Use Policy 2015, 45, 26-35. [CrossRef]

44. Vecchione, G. EU Rural Policy: Proposal and Application of an Agricultural Sustainability Index. Munich Personal RePEc Archive Papers No. 27032. 2010. Available online: http:/ / mpra.ub.uni-muenchen.de/27032/ (accessed on 10 June 2017).

45. Rural Development Strategy of Romania 2014-2020. Available online: http:/ /bit.ly/2sfb571 (accessed on 10 June 2017).

46. Romania's National Competitiveness Strategy 2014-2020. Available online: http:/ /bit.ly /1JkcZlk (accessed on 10 June 2017).

47. Romanian Government. The National Strategy for Research, Development and Innovation 2014-2020. Available online: http:/ / bit.ly/1t4iNwG (accessed on 18 April 2017).

48. Fagerberg, J. Schumpeter and the revival of evolutionary economics: An appraisal of the literature. J. Evol. Econ. 2003, 13, 125. [CrossRef]

49. Schumpeter, J. The Theory of Economic Development: An Inquiry into Profits, Capital, Credit, Interest, and the Business Cycle; Transaction Publishers: Piscataway, NJ, USA, 1934.

50. Cavallini, S.; Soldi, R.; Friedl, J.; Volpe, M. Using the Quadruple Helix Approach to Accelerate the Transfer of Research and Innovation Results to Regional Growth. Consortium Progress Consulting S.r.l. E Fondazione FORMIT. Available online: http:/ / bit.ly/2zgInpZ (accessed on 29 October 2017).

51. European Commision, National/Regional Innovation Strategies for Smart Specialization. 2014. Available online: http:/ / bit.ly/1SIK8M5 (accessed on 18 April 2017).

52. Giannakis, E.; Bruggeman, A.; Djuma, H.; Kozyra, J.; Hammer, J. Water pricing and irrigation across Europe: Opportunities and constraints for adopting irrigation scheduling decision support systems. Water Sci. Technol. 2016, 16, 245-252. [CrossRef]

53. Horizon 2020-Work Programme 2014-2015: Technology Readiness Levels (TRL). Available online: http:/ / bit.ly/2iGC1XP (accessed on 9 July 2017).

54. The UASVM Cluj-Napoca 2015-2016 Rector Reports. Available online: http:/ /bit.ly/2eYe0bt (accessed on 14 September 2017).

55. Pianta, M. Innovation and economic change. Econ. Innov. New Tech. 2017, 26, 683-688. [CrossRef]

56. Yun, J.J.; Won, D.; Jeong, E.; Park, K.; Lee, D.; Yigitcanlar, T. Dismantling of the Inverted U-Curve of Open Innovation. Sustainability 2017, 9, 1423. [CrossRef]

57. Brylina, I.V.; Nikitina, J.A.; Brylin, V.I.; Chaplinskaya, Y.I. The Knowledge Market and the Idea of Entrepreneurship in the Modern University. Eur. Proc. Soc. Behav. Sci. 2017, 19, 110-117. Available online: http:/ / bit.ly/2gyo9jE (accessed on 20 October 2017).

58. Metcalfe, J.S.; Ramlogan, R. Limits to the economy of knowledge and knowledge of the economy. Futures 2005, 37, 655-674. [CrossRef]

59. Gotts, N.M. Resilience, panarchy, and world-systems analysis. Ecol. Soc. 2007, 12, 24. [CrossRef]

60. Bertus, C.; Khosrojerdi, A.; Panchal, J.H.; Janet, K.A.; Farroch, M. Identifying dilemmas embodied in 21st century engineering. In Proceedings of the ASME International Design Engineering Technical Conferences and Computers and Information in Engineering Conference, Chicago, IL, USA, 12-15 August 2012; Volume 7, pp. 161-174.

61. Davies, A.R. Cleantech clusters: Transformational assemblages for a just, green economy or just business as usual? Glob. Environ. Chang. 2013, 23, 1285-1295. [CrossRef]

62. Bifulco, F.; Tregua, M.; Amitrano, C.C. Co-governing smart cities through Living Labs. Top evidences from EU. Transylv. Rev. Adm. Sci. 2017, 13, 21-37.

63. The 6th Annual Forum of the EU Strategy for the Danube Region. Available online: http://www.danubeforum-budapest.eu/ (accessed on 20 October 2017). 
64. Martin, S.; Orodan, E.; Tonea, E.; Sirbu, C.; Ciolac, R.; Lile, R. Client-Basic element in the frame of public food service. J. Biotechnol. 2015, 208, S80. [CrossRef]

65. Tigu, G.; Iorgulescu, M.-C.; Ravar, A.S.; Lile, R. A Pilot Profile of the Social Entrepreneur in the Constantly Changing Romanian Economy. Amfiteatru Econ. 2015, 17, 25-43.

66. Yun, J.J.; Jeong, E.; Lee, C.; Park, J.; Zhao, X. Effect of Distance on Open Innovation: Differences among Institutions According to Patent Citation and Reference. Sustainability 2017, 9, 1478. [CrossRef]

(C) 2017 by the authors. Licensee MDPI, Basel, Switzerland. This article is an open access article distributed under the terms and conditions of the Creative Commons Attribution (CC BY) license (http:/ / creativecommons.org/licenses/by/4.0/). 